\title{
TTR
}

Traduction, terminologie, re?daction

\section{Code-Switching and Code-Mixing in African Creative Writing: Some Insights for Translation Studies}

\section{Paul Bandia}

Volume 9, numéro 1, 1er semestre 1996

Le festin de Babel

Babel's Feast

URI : https://id.erudit.org/iderudit/037242ar

DOI : https://doi.org/10.7202/037242ar

Aller au sommaire du numéro

Éditeur(s)

Association canadienne de traductologie

ISSN

0835-8443 (imprimé)

1708-2188 (numérique)

Découvrir la revue

Citer cet article

Bandia, P. (1996). Code-Switching and Code-Mixing in African Creative Writing: Some Insights for Translation Studies. TTR, 9(1), 139-153.

https://doi.org/10.7202/037242ar
Résumé de l'article

L'alternance et le mélange de codes dans la création littéraire africaine : contribution à la traductologie - L'alternance de codes et le mélange de codes sont deux procédés caractéristiques de la création littéraire africaine. Ces procédés y jouent un rôle primordial dans la mesure où ils ont une valeur sociolinguistique, referentielle et discursive. Cet article a pour objet l'étude de l'emploi, par les auteurs africains, de l'alternance et du mélange de codes comme choix linguistiques afin d'assurer certaines fonctions pragmalinguistiques dans un texte littéraire. Notre but est de démontrer comment l'exploitation de ce type de 'mélange de langues' comme mode de création littéraire implique l'usage de stratégies de traduction spécifiques. Par ailleurs, il est question de voir comment la traduction de textes comprenant une alternance ou un mélange de codes fait appel à des techniques susceptibles d'enrichir nos connaissances du processus de la traduction.
Tous droits réservés @ C TTR: traduction, terminologie, rédaction — Les auteurs, 1996 cest protégé par la loi sur le droit d'auteur. L’utilisation des services d'Érudit (y compris la reproduction) est assujettie à sa politique d'utilisation que vous pouvez consulter en ligne. 


\section{Code-switching and code-mixing in African creative writing: Some insights for translation studies}

\section{Paul Bandia}

\section{Introduction}

Faced with the need to make their works available to a wide international readership, African writers are at times forced to relate their worldviews in Western colonial languages which do not often lend themselves easily to expressing African sociocultural reality. To cope with this artistic dilemma, African writers employ various writing techniques to capture and convey the various facets of African life. A characteristic feature of African creative writing is the use of code-switching (CS) and code-mixing (CM) as a writing technique. CS and CM have a social, discursive and referential significance in a text.

In language contact studies, there has not been a clear consensus on the appropriate definitions of various results of language contact situations such as borrowing, interference, transfer, shift, relexification, pidginization and creolization. Some scholars have chosen the term "mixing" as a neutral cover term for both code-switching and borrowing. However, borrowing can occur in the speech of those with only monolingual competence, while codeswitching implies some degree of competence in the two languages. 
Gumperz defines CS as "the juxtaposition within the same speech exchange of passages of speech belonging to two different grammatical systems or subsystems" (1982, p. 59). In code-switched discourse, the items in question form part of the same speech act. They are tied together prosodically as well as by semantic and syntactic relations equivalent to those that join passages in a single speech act (Romaine 1989, p. 111).

Singh $(1985$, p. 34$)$ reserves the term 'code-mixing' for intrasentential switching and uses 'code-switching' for any diglossic situation where only one code is employed at a time, or cases where the code alternation refers to structurally identifiable stages or episodes of a speech event.

Poplack (1980) outlines three major types of CS: 'tagswitching', 'intersentential' and 'intrasentential' switching.

- 'Tag-switching' involves the insertion of a tag in one language into an utterance which is otherwise entirely in the other language (e.g. Bon, let's see what we can do).

- 'Intersentential' switching involves a switch at a clause or sentence boundary, where each clause or sentence is in one language or another. A well-known example from Puerto Rican bilingual Spanish/English speech is the statement: "Sometimes I'll start a sentence in English y termino en español."

- 'Intrasentential' switching involves switching of different types which occurs within the clause or sentence boundary (e.g. As-tu vu le movie where Mel Gibson joue le maverick?)

However, it is also pointed out that all three types of codeswitching may be found within one and the same discourse.

\section{Forms of CS in African Creative Writing}

In this paper, we are more interested in the pragmatic rather than the grammatical aspects of code-switching. The study of CS is basically an analysis of parole (as opposed to langue) as the investigation must concern itself with a corpus of performance. CS and CM are 
used to signal social, discourse and referential meaning in a text. African writers use them to express certain specific functions in a social interaction situation, and also some community-specific ways of communicating.

The most common form of CS and CM used by African writers is that between vernacular language and the European language. When African writers cannot adequately express African sociocultural reality in a European language, they resort to the use of indigenous words and expressions. African novels in European languages are often replete with words and expressions from the native languages of the characters in the novel. The presence of indigenous words and expressions constitutes a problem not only for non-African readers, but also for other Africans who are not from the same linguistic group as the author or the characters in the novel. Sometimes guessing the meaning of these words and expressions is virtually impossible and that is why there is quite often a footnote, or a glossary to explain them. However, since footnotes and glossaries can become quite cumbersome, interrupting the smooth flow of the text, some authors resort to a very subtle form of in-text translation (thus creating a code-switched or codemixed text).

In-text translation is an attempt to clarify the meaning of a foreign language word, expression, clause or sentence within an utterance which is otherwise entirely in the main language of writing or expression. This translation technique seeks to elucidate foreign language items in an utterance by providing clarification within one and the same discourse. The reader is thus informed about the meaning and the artistic merits (significance) of the foreign items without the intrusion of a deliberate attempt to translate.

In African Europhone literature, in-text translation may take the form of an explanation, a translation or a gloss which is sometimes placed in apposition to the indigenous word or expression. For example, 
(1) He is Okonkwo kpom-kwem, exact, perfect (Things Fall Apart, p.49).

(2) The proper name for a corn-cob with only a few scattered grains was eze-agadi-nwayi, or the teeth of an old woman (Things Fall Apart, p. 25).

(3) Where did you bury your iyi-uwa? ... You buried it in the ground somewhere so that you can die and return again to torment your mother (Things Fall Apart, p. 57).

Example (1) is a case of 'intrasentential' switching in which the meaning of the Igbo expression $k$ pom-kwem is carefully rendered by the adjectives 'exact, perfect.' However, even juxtaposing the adjectives does not come close to capturing the stylistic significance of the Igbo term as expressed in its rhythmic and onomatopoeic qualities. Example (2) is an instance of 'intersentential' switching. Eze-agadi-nwayi is a complete statement in Igbo and its gloss translation "the teeth of an old woman" is introduced by an "or" as if it were just an alternative, an after-thought, meant for a non-Igbo person who might be listening. Number (3) is another example of 'intrasentential' switching. The term iyi- $u w a$ is heavily charged with mythological beliefs and traditional lore. Obviously, the author, Achebe, realizes that merely providing a gloss translation of the term will not be of much help to the non-Igbo reader. He thus follows the term with an elaborate "in-text" explanation which can only begin to shed some light on this complex item of Igbo, and for that matter, African mythology. The example alludes to a prevailing belief among some African peoples that some babies have the ability to cause their own death if they are unhappy about the treatment they get, and can return to torment their parents. Iyi-uwa is a kind of talisman the babies are supposedly born with, which is a symbol of their magical powers. If a local witch-doctor can find and destroy the talisman, the baby will lose its magical powers and this will put an end to what amounts to a cycle of torment. 
In the following example, the authors attempts to create humour by making one of his European characters translate an obscene expression from the author's native language:

(4) Pour eux, je n'étais plus que 'Ngovina ya ngal a ves zut bisalak a be metua'! Sais-tu ce que cela veut dire? Bien sûr que non! Tu as toujours méprisé les dialectes indigènes ... Eh bien, partout où je passe, je ne suis plus que le Commandant dont la femme écarte les jambes dans les rigoles et dans les voitures (Une vie de boy, pp. 149-150).

Besides creating humour, in-text translation is used here to highlight the sense of drama the native statement is meant to convey. The comic aspect of the statement is brought out as the French Commandant, who thinks he is fluent in the local vernacular, tries to show off to his much-too-European wife. It is left to the imagination of the reader to see how this colonialist is being ridiculed not only as a cuckold husband, but also as a colonial administrator spewing out the native words with a non-native flair, as was characteristic of the very zealous among the colonialists. The translation is literal and the language is explicit. The statement is more dramatic and even more potent in French, as it is not unusual to use such explicit language in African oral tradition.

The main motivation for the use of native words and expressions is their sociocultural relevance. The explanation, translation or gloss placed in apposition to the native words might indeed sometimes appear repetitive and redundant, since they merely repeat what has been expressed in the indigenous language and make it coherent. Yet, the effect would not be the same if the native words or expressions were not used. Besides preserving meaning and compensating for a lack of adequate terminological equivalence, native words and expressions add local colour to the text, and putting them side-by-side with their gloss, explanation or translation, enriches the text from a stylistic point of view. 
Furthermore, in this type of code-switching practised by African writers, the native words and expressions are not particularly intrusive for readers. The author's European language of writing in which they are found does not often appear to have suffered any major violation of its lexico-grammatical structure. The reason for this is that the native words and expressions are usually used in such a way that they fit in with the syntactic and grammatical characteristics of the European language. In other words, they agree grammatically and syntactically with what sociolinguists refer to as "constraints" on code-mixing and code-switching. That is, the slot in which the native words and expressions are placed is a part and function of the grammar and native intuition of the speaker. The semantic interpretation of the native word or expression does not violate the selectional restrictions, co-occurrence or collocation in the total or immediate compositionality of the sentence in which it occurs. The only difference is its unacceptability from the point of view of the speaker of the European variety of the language in question. Thus, through $\mathrm{CS}$ and $\mathrm{CM}$, African writers use native words and expressions in their works, as a means of achieving relevance and authenticity and local colour without necessarily modifying the grammatical structure of the European language of writing.

\section{Some Pragmalinguistic Functions of CS}

In African creative writing $\mathrm{CS}$ and $\mathrm{CM}$ are used to highlight certain pragmatic functions such as foregrounding, identity, focusing, distancing, and neutralization.

Identity is used here to mean the use of language as a means of solidarity, kinship and other types of group membership.

Focusing, on the other hand, is the use of language to isolate the addressee as the sole intended listener to the utterance in question.

Distancing has the force of saying to the listener "you are outside (excluded), or venerable, or young, or old, etc." 
Foregrounding is the tendency in CS and CM speech interaction for the speaker to use a code that appeals to one person. It is the opposite of neutralization which is the use of mixing and switching to neutralize the effect the message would have if carried in another code.

The following example is an illustration of the use of these pragmalinguistic functions in African literature.

'You can now see, Son of our Daughter, that we cannot get
our elders together before tomorrow,' said Otikpo.

'If a war came suddenly to your town how do you call your men together, Father of my Mother? Do you wait till tomorrow? Do you not beat your Ikolo?' asked Akukalia. (Arrow of God, p. 23)

In traditional African society, kinship relations are often expressed in ways that are foreign to Western culture. References to kinship relations are often expressed in terms of phrases that are explicit explanations of the kind of family ties there are between relatives. In the above text from Achebe's Arrow of God, the expression Son of our Daughter is used by a maternal grand-uncle to refer to the son of his niece. The 'son' in turn refers to his maternal grand-uncle as Father of my Mother since the grand-uncle could very well represent his maternal grand-father who is no longer alive.

From a pragmalinguistic point of view these kinship references, which are literal translations from Igbo, play a significant role in the text. For instance, the references are used as a focusing or a foregrounding technique. The young man, Akukalia, is sent by his father's village on an important errand to his mother's village. The two villages are on the brink of war and Akukalia has been sent to ask his mother's people to choose between war and peace. His maternal grand-uncle, who is aware of Akukalia's mission, refers to him as Son of our Daughter in order to remind Akukalia of his blood ties with his mother's relatives to whom he is about to deliver 
a message of war. The kinship reference thus expresses the pragmatic function of identity. Akukalia retorts by calling his maternal grand-uncle Father of my Mother, thus acknowledging the kinship ties between them, but also, it can be argued, attempting to create distance between himself and his maternal relatives against whom his father's village (and, according to tradition, his own village) is about to wage war. The sense of distance between the speaker and his grand-uncle can be gauged by the apparent rudeness of a younger man trying to "lecture" an elder on the customs of his people. The question is framed in a rhetorical manner and indeed does not solicit an answer, as the custom in this matter of war is clear to both parties. It can also be argued that the form of address used here can also play the pragmatic role of neutralizing (or softening) the question. If the form of address were deleted, the question would seem direct, contemptuous and lacking in tact. Context is, therefore, quite instrumental in determining what kind of pragmalinguistic function a form of address or reference is meant to express.

I would like to focus here on the pragmalinguistic function of asserting identity and in-group solidarity. As mentioned earlier, identity is used here to mean the use of language as a means of solidarity, kinship and other types of group membership. In the study of language in its social context, "CS has held a central place as the paradigmatic example of systematic linguistically striking, and socially meaningful linguistic variation" (Gal 1988, p. 245). In postcolonial Africa, CS often occurs between adopted colonial languages and the local or native languages. The colonial language which is often the State-authorized language, is usually used as a symbol of power and prestige. Hence, CS usually involves the use of a Statesupported and powerfully legitimated language in opposition to an often stigmatized minority language that has considerably less institutional support. CS shows us "how speakers respond symbolically to relations of domination between groups within the State, and how they understand their historic position and identity within a world capitalist system structured around dependency and unequal development" (Gal 1988, p. 247). Often, in this context, CS and $\mathrm{CM}$ are the result of a long history of struggles for political and 
economic resources and other forms of power. CS and CM are thus used by ethnic groups to prop up their resistance to dominant languages. Hence, to understand $\mathrm{CS}$ in such a context, an integration of conversational, ethnographic and socio-historical evidence is required.

In post-colonial Africa, a standard dialect (colonial language) gains its legitimacy from state-sponsored institutions such as education, thus inculcating the dialect's authority, imposing it even on speakers of dominated classes who never master it. This may foster respect for linguistic varieties one does not speak, and deprecation of one's own language, a linguistic phenomenon that has been referred to as "symbolic domination" (Bourdieu, 1977). And just as a local response to dominant cultures is sometimes an oppositional culture, so the authority of the "standard" dialect does not go unchallenged (Woolard, 1985). The unauthorized vernacular forms continue to be used because they enact values of solidarity, opposing the dominant value of status and prestige. Hence, in some instances, CS practices of bilingual (or multilingual) minorities can be viewed as resistance to the domination or attempted domination of state-authorized languages (such as colonial languages). Indeed, for language groups facing a dominant culture that imposes external images of them, CS has become a means of establishing the authority of the minority language and the power of the linguistic group.

The unequal power relations characteristic of the postcolonial setting bring about the diverse local responses linguistic groups construct to material and cultural domination. Among such responses in the African setting, is the creation of hybrid languages such as pidgins and creoles, which are a mixture, or blend, of imported European languages and local vernacular languages. In the works of African writers, these PCs have become a sure means of mixing languages as a writing technique.

Besides enhancing the local colour of a text, PCs are sometimes used by speakers to ensure group solidarity. They have become a private code used as a form of resistance to the dominant 
colonial language. Quite often this mixed language is used in a three-tier CS process, namely: vernacular - Pidgin/Creole - French/ English. The reasons for using these techniques are aesthetic, sociological and historical. The following passage from Achebe's Arrow of God shows how two African policemen working for the colonial administration would speak to their countrymen in the local vernacular but would confer with each other in Pidgin English, as if it had become a private code for a new class of Africans:

(5) - 'Which one of you is called Ezeulu?' asked the corporal.

- 'Which Ezeulu?' asked Edogo.

- 'Don't ask me which Ezeulu again or I shall slap okro seeds [teeth] out of your mouth. I say who is called Ezeulu here?'

- 'And I say which Ezeulu? Or don't you know who you are working for?' [...]

- 'All right,' said the corporal in English.

- 'Jus now you go sabby which Ezeulu. Gi me dat ting [handcuffs]'.

(This last sentence was directed to his companion who immediately produced the handcuffs from his pocket). (Arrow of God, p. 152)

This passage is another example of how African writers seek to embellish their texts by alternating a standard colonial language with a locally formed variety. From an aesthetic point of view, the passage enhances the authentic character of African creative writing. From a socio-historical standpoint, it is an illustration of the social cleavage brought about by the colonial reality. These policemen, who think they are speaking standard English, seek to distinguish themselves from the local villagers by showing off their knowledge of the 'whiteman's language'. Pidgin thus becomes a means to vaunt their privileged position in colonial society. They assume an air of superiority when dealing with the villagers, as they consider themselves fortunate enough to be working for the colonial administration which represents the real power overriding the power of the local chiefs. It is rather ironic 
that such a hybrid language becomes the rallying point (in-group solidarity) for a group of colonized people who would stop at nothing to oppress and exploit their own people. Pidgin thus replaces English in its role as the language of oppression and symbol of colonial power.

In Things Fall Apart Chinua Achebe uses a Pidgin word in an English sentence for local colour:

(6) Ezinma had been making inyanga with her pot (Things Fall Apart, p. 3).

The word means 'showing off', and is used here to reflect the kind of showing off that little boys and girls indulge in. Ezinma attempts a balancing act with a pot of clay on her head.

In $A k e$, Wole Soyinka uses another Pidgin word:

Look how we sleep like munmu. (Ake, p. 191) (the word refers to deaf people)

Examples (6) and (7) have the pragmalinguistic function of identity and solidarity in their respective novels. Both authors seek to highlight the African character of their novels. Achebe shows how the use of an indigenous word like inyanga brings a village community together. The word informs the reader about day-to-day life in the village. The people share a common lore, a common belief system and a tradition which gives them a sense of belonging, a sense of identity and group membership. Soyinka, whose novel deals with a more urban setting where Pidgin is fast becoming a lingua franca, highlights the differences in social class of the characters in his novel. Although Pidgin is also spoken by members of the educated elite, often as a means of ensuring in-group solidarity, it has remained, for the most part, the contact language spoken by the 'illiterate' and 'semi-literate' masses of the urban centres. Example (7), like most occurrences of hybrid languages in Soyinka's works, is used to mark the kind of social stratification that is part of life in modern African cities. The urban poor uses Pidgin, 
which is the language that comes naturally to him, to isolate and distance himself from the educated Westernized elite.

\section{Translation of Texts using CS}

It is also interesting to see how translators of African literature cope with the translation of these hybrid languages. It has been said that the French-based pidgins of West-Africa are not as stable as the English-based pidgins (for historical reasons). Now, let us see how the much less codified French-based pidgin is translated into the more codified English-based pidgin. The following are examples taken from Ferdinand Oyono's Une vie de boy and their translations:

(8) Monz'ami, ... nous pas buveurs indigènes! (Une vie de boy, p. 77)

Man ... We no be native drinkers (Reed 1966, p. 49)

(9) Petit Joseph pati rôti en enfer (Une vie de boy, p. 34) Small Joseph go burn in hell (Reed 1966, p. 22)

(10) Yen a vérité, Sep [Chef] (Une vie de boy, p. 39) It's truth, sah (Reed 1966, p. 25)

In these translations Reed attempts to render 'broken' French by 'broken' English. He followed the French text very closely in order to come up with what he imagines to be the kind of English spoken by such characters in the novel. Yet, it would have been more appropriate for him to seek the help of native speakers of West African Pidgin English (WAPE), which would have led to translations that are more representative of the kind of pidgin English spoken by such characters in the West-African setting. For example,

(11) Massa, ... we no de drink mimbo laik bush people!

(12) Smal Joseph, i go burn fo hell fire.

(13) Na true, sah. 
Reed's translations are hardly authentic renditions of WAPE, and they remind one of the kind of 'broken' English spoken by European missionaries as they tried to communicate with the native people. As indicated in example (11), bush people is a more likely term in Pidgin than Reed's native drinkers in (8), which is a little too 'English' and is unavailable to the illiterate speaker of Pidgin. In example (9), Reed's rendition, go bum in hell, sounds more English than the usual Pidgin expression go brom fo hell fire suggested in (12). In examples (10) and (13), Na true, sah is more likely to occur in Pidgin than It's truth, sah. $\mathrm{Na}$ is the recognized equivalent of It's in Pidgin, while the noun 'truth' is rarely used (see Todd, 1982, 1984).

\section{Conclusion}

Thus, CS and CM practices should be viewed not only as interactional and socio-political linguistic phenomena, resulting from obvious historical and ideological forces but also as conversational tools that maintain or change ethnic group boundaries and personal relationships (Gal 1988, p. 247). Translating code-switched and code-mixed texts requires thorough knowledge of the pragmalinguistic functions of CS and CM in the texts. African writers seem to have understood this fact very well, and have sought to embellish their works with this writing technique. They have thus played the role of translators in trying to capture this aspect of African oral tradition in European languages. A careful study of the translation of such code-mixed and code-switched texts which are closely guided by the socio-cultural rules of communication in a given linguistic community can enhance our understanding of the translation process.

\section{References}

ACHEBE, C. (1958). Things Fall Apart. London, Heinemann. (1964). Arrow of God. London, Heinemann. 
BOURDIEU, P. (1977). "The Economics of Linguistic Exchanges," Social Science Information, 16, pp. 645-668.

GAL, S. (1988). "The Political Economy of Code Choice," Heller, M., ed. (1988), pp. 245-264.

GUMPERZ, J. J. (1982). Discourse Strategies. Cambridge, Cambridge University Press.

HELLER, M., ed. (1988). Codeswitching. Amsterdam, Mouton.

JACOBSON, R, ed. (1990). Codeswitching as a Worldwide Phenomenon. New York, Peter Lang.

OYONO, F. (1956). Une vie de boy. Paris, Éditions Julliard.

(1966). Houseboy. Trans. by J. Reed. London, Heinemann.

POPLACK, S. (1980). "Sometimes I'll start a sentence in English Y TERMINO EN ESPAÑOL: Towards a Typology of CodeSwitching," Linguistics, 18, pp. 581-618.

ROMAINE, S. (1989). Bilingualism. Oxford, Blackwell.

SINGH, R. (1985). "Grammatical Constraints on Code-Switching: Evidence from Hindi-English," Canadian Journal of Linguistics, 30, pp. 33-45.

TODD, L. (1982). Varieties of English Around the World: Cameroon. Heidelberg, Julius Groos Verlag.

Blackwell.

(1984). Modern Englishes: Pidgins and Creoles. Oxford,

WOOLARD, K. (1985). "Language Variation and Cultural Hegemony: Toward an Integration of Sociolinguistic and Social Theory," American Ethnologist, XII(4), pp. 738-748. 
ABSTRACT : Code-switching and code-mixing in African creative writing: some insights for translation studies - A characteristic feature of African creative writing is the use of codeswitching and code-mixing as a writing technique. Code-switching and code-mixing have a discourse, referential and sociolinguistic significance in a text. This paper deals with how African writers use various forms of code-switching and code-mixing as linguistic choices having specific pragmalinguistic functions in a text. Our aim is to show how exploiting this type of 'language mixing' for literary creativity calls for specific translation strategies and, how translating code-switched and code-mixed texts requires techniques that can help us enhance our knowledge of the translation process.

$R E ́ S U M E ́$ : L'alternance et le mélange de codes dans la création littéraire africaine: contribution à la traductologie - L'alternance de codes et le mélange de codes sont deux procédés caractéristiques de la création littéraire africaine. Ces procédés y jouent un rôle primordial dans ta mesure où ils ont une valeur sociolinguistique, référentielle et discursive. Cet article a pour objet l'étude de l'emploi, par les auteurs africains, de l'alternance et du mélange de codes comme choix linguistiques afin d'assurer certaines fonctions pragmalinguistiques dans un texte littéraire. Notre but est de démontrer comment l'exploitation de ce type de 'mélange de langues' comme mode de création littéraire implique l'usage de stratégies de traduction spécifiques. Par ailleurs, il est question de voir comment la traduction de textes comprenant une alternance ou un mélange de codes fait appel à des techniques susceptibles d'enrichir nos connaissances du processus de la traduction.

Paul Bandia: Université des Antilles et de la Guyane, Faculté des lettres et des sciences humaines, B. P. 7207, 97275 Schoelcher Cedex, Martinique 